Tarbawi: Jurnal Ilmu Pendidikan p-ISSN:1858-1080 | e-ISSN: 2615-6547

Vol. 16, No. 1, Juli 2020, 37-45

\title{
Pengaruh Teknik Pembelajaran Pictorial Riddle Berbantukan LKPD Berbasis Inquiry Learning Terhadap Keterampilan Proses Sains pada Materi Pemantulan Cahaya
}

\author{
Reny Widyanti, I Wayan Distrik, Ismu Wahyudi \\ Universitas Lampung \\ E-mail: renywidyanti02@gmail.com
}

\begin{abstract}
Abstrak. Pengaruh Teknik Pictorial Riddle Berbantukan LKPD Inquiry Learning terhadap keterampilan proses sains. Penelitian ini dilakukan dengan tujuan untuk mengetahui pengaruh teknik pembelajaran pictorial riddle berbantukan LKPD berbasis inquiry learning terhadap keterampilan proses sains peserta didik. Penelitian ini dilakukan di SMP Negeri 8 Bandarlampung dengan menggunakan desain penelitian non equivalent control group design. Hasil uji independent sample t-test diperoleh perbedaan $\mathrm{N}$-gain yang signifikan dengan nilai signifikan sebesar 0,000 dan effect size sebesar 0,9 yang berarti terdapat pengaruh penggunaan teknik pembelajaran pictorial riddle berbantukan LKPD berbasis inquiry learning terhadap keterampilan proses sains dengan size pengaruh dalam kriteria besar.
\end{abstract}

Kata kunci: Pictorial riddle, inquiry learning, keterampilan proses sains

\begin{abstract}
Effect of pictorial riddle technique assisted by lkpd inquiry learning on science process skills. This research was conducted with the aim to determine the effect of pictorial riddle learning techniques assisted by inquiry learning based on lkpd on the science process skills of students. This research was conducted at SMP Negeri 8 Bandarlampung using a non equivalent control group design. Independent sample t-test results obtained a significant n-gain difference with a significant value of 0,000 and an effect size of 0.9 which means there is an influence of the use of pictorial riddle learning techniques assisted by inquiry learning based on lkpd on science process skills with a size of influence in large criteria.
\end{abstract}

Keywords: pictorial riddle, inquiry learning, science process skills 


\section{PENDAHULUAN}

Pendidikan abad-21 menuntut lembaga-lembaga pendidikan yang dikelola secara profesional untuk menghasilkan sumber daya manusia yang berkualitas. Keahlian atau kompetensi yang harus dimiliki oleh sumber daya manusia di abad-21, yaitu: 1) kemampuan berpikir kritis dan melakukan pemecahan masalah, 2) kemampuan berkomunikasi dan bekerja sama, 3) kemampuan mencipta dan memperbaharui, 4) literasi teknologi informasi dan komunikasi, 5) kemampuan belajar kontekstual, 6) kemampuan informasi dan literasi media (BSNP, 2010)

Berdasarkan tuntutan pendidikan abad-21 tersebut, maka guru harus memiliki kemampuan menerapkan pembelajaran yang bersifat student centered. Salah satu teknik pembelajaran yang mendukung pembelajaran abad-21 adalah teknik pembelajaran pictorial riddle. Teknik pembelajaran pictorial riddle mampu melatihkan keterampilan proses sains, salah satunya adalah keterampilan berpikir kritis dan keterampilan pemecahan masalah fisika, sehingga dapat memenuhi salah satu tuntutan pendidikan abad-21. Hal ini sesuai dengan pernyataan dari (Anggraini et al., 2018) yang menjelaskan bahwa pictorial riddle merupakan salah satu pembelajaran inkuiri yang dapat meningkatkan motivasi peserta didik, kemampuan berpikir kritis, dalam memecahkan permasalahan. Pembelajaran abad-21 membutuhkan startegi pembelajaran yang mendukung tercapaianya tujuan pembelajaran.

Pictorial riddle merupakan suatu teknik, cara atau upaya pembelajaran yang menginformasikan fakta ilmiah kepada peserta didik melalui gambar yang disajikan dalam bentuk poster, gambar di papan tulis, atau proyeksi dari suatu transparansi objek. (Al et al., 2018) berpendapat bahwa teknik picorial riddle dapat mengembangkan aktivitas siswa pada saat proses pembelajaran berlangsung melalui penyajian masalah yang disajikan dalam bentuk ilustrasi. Penerapan teknik pictorial riddle biasanya menggunakan media berupa gambar atau peragaan dari situasi yang sebenarnya. Menurut pendapat Dewi, dkk. (2013) teknik pictorial riddle memberikan kesempatan kepada peserta didik untuk memecahkan masalah, menganalisis, membuktikan, dan menarik kesimpulan secara mandiri melalui gambar, peragaan, atau ilustrasi dari keadaan yang sesungguhnya, sehingga peserta didik lebih termotivasi dan percaya diri untuk mengemukakan pendapatnya dalam proses pembelajaran. Berdasarkan beberapa pendapat tersebut, maka dapat dikatakan bahwa teknik pictorial riddle merupakan suatu teknik pembelajaran yang digunakan untuk menampilkan suatu permasalahan dalam bentuk gambar atau ilustrasi yang dapat mengembangkan keaktifan, meningkatkan motivasi belajar, dan meningkatkan keterampilan proses sains.

Ada beberapa hal pendukung yang digunakan dalam proses pembelajaran untuk meningkatkan keterampilan proses sains yaitu dengan menggunakan media pembelajaran, salah satunya adalah Lembar Kerja Peserta Didik (LKPD). LKPD di desain sesuai dengan model, tujuan 
dan karakteristik pembelajaran dan materi yang akan dipelajari. LKPD yang dirancang untuk meningkatkan keterampilan proses sains salah satunya adalah LKPD berbasis inquiry learning. Inquiry learning merupakan salah satu model pembelajaran yang melibatkan peserta didik dalam menemukan suatu konsep dari materi yang sedang dipelajari. Tahap-tahap pembelajaran inquiry dapat menunjang keterampilan proses sains peserta didik menurut Rahmasiwi, dkk. (2015), selanjutnya didukung oleh penelitian Hartini (2017) yang menyatakan bahwa model pembelajaran levels of inquiry dapat meningkatkan keterampilan proses sains peserta didik dengan kategori tinggi. Berdasarkan beberapa pendapat tersebut, maka dapat dikatakan bahwa inquiry learning merupakan salah satu model pembelajaran yang melibatkan peserta didik secara aktif sehingga dapat memberikan pengaruh terhadap keterampilan proses sains.

Faktanya beberapa guru di sekolah masih terfokus pada penilaian kognitif dan lebih mengutamakan pemahaman materi supaya peserta didik dapat mengerjakan soal-soal ujian dan memperoleh nilai di atas standar kelulusan. Permasalahannya pada kurikulum 2013 penilaian harus mencakup aspek kognitif, afektif, dan psikomotor, sehingga keterampilan proses sains menjadi salah satu aspek psikomotor yang terintegarasi dalam kurikulum 2013. Sebagai salah satu kebijakan untuk meinimalisir kendala tersebut, maka diperlukan desain model pembelajaran yang memanfaatkan media sehingga peserta didik mampu mengamati fenomena secara langsung dan melibatkan lebih banyak indera dalam proses pembelajaran. Hal tersebut sesuai dengan penelitian (Paul M. Muchinsky, 2012) pembelajaran yang dirancang secara baik dan kreatif dengan memanfaatkan multimedia, dalam batas-batas tertentu akan dapat memperbesar kemungkinan siswa untuk belajar lebih banyak mencamkan apa yang dipelajarinya, lebih baik, dan meningkatkan penampilan (performance) siswa dalam rangka meningkatkan ketercapaian kompetensi. Media sebagai bagian integral pembelajaran, komponen ini perlu mendapatkan perhatian para guru. Pentingnya media dalam memfasilitasi peserta didik (pebelajar), penyajiannya disesuaikan dengan tujuan pembelajaran yang ditetapkan. Hadirnya media dalam proses pembelajaran sangat membantu pebelajar lebih memahami hal yang dipelajari.

Analisis penelitian pendahuluan di sekolah menghasilkan informasi bahwa pembelajaran IPA khusunya fisika masih sering menggunakan startegi pembelajaran ekspositori. Guru menyatakan bahwa peserta didik hanya mampu menjelaskan definisi, sedikit prinsip dan konsep dari suatu materi fisika, namun ketika guru memberikan kesempatan kepada peserta didik untuk melakukan eksperimen, peserta didik cenderung kesulitan menganalisis dan mengaitkan data hasil percobaan dengan konsep. Hal ini diakarenakan selama proses pembelajaran peserta didik hanya diberikan konsep yang sudah jadi tanpa adanya suatu treatment yang dapat meningkatkan keterampilan proses untuk menemukan konsep dalam pembelajaran IPA. Tujuan dilakukannya penelitian ini adalah 
mengetahui pengaruh teknik pembelajaran pictorial riddle berbantukan LKPD berbasis inquiri learning terhadap keterampilan proses sains peserta didik.

\section{METODE}

Populasi pada penelitian ini adalah seluruh peserta didik kelas VIII SMP Negeri 8 Bandarlampung yang terdiri dari empat kelas. Sampel penelitian diambil secara purposive sampling yaitu pemilihan kelas sebagai sampel dengan karakteristik yang relatif homogen. Pengambilan sampel dilakukan dengan melihat hasil ujian semester dari empat kelas tersebut, kemudian dipilih dua kelas yang memiliki nilai rata-rata yang relatif sama. Metode penelitian yang digunakan adalah eksperimen semu atau quasi elesperimental dengan desain penelitian non equivalent control group design.

Kelas eksperimen diberi perlakuan dengan menggunakan teknik pembelajaran pictorial riddle berbantukan LKPD berbasis inquiry learning dan kelas kontrol menggunakan pembelajaran dengan metode ceramah berbantukan LKPD berbasis ekspositori atau konvensional yang menekankan penyampaian materi secara verbal kepada peserta didik. Sebelum diberi perlakuan, terlebih dahulu peserta didik diberikan pretest untuk mengukur kemampuan awal peserta didik, dan setelah pembelajaran selesai peserta didik diberikan tes akhir atau posttest. Selanjutnya hasil pretest dan posttest dari kedua kelas tersebut dilihat perbandingan nilai $N$-gainnya.

Instrumen penelitian yang digunakan dalam penelitian ini adalah tes berupa soal keterampilan proses sains. Sebelum digunakan sebagai instrumen penelitian, soal terlebih dahulu harus diuji validitas dan reliabilitasnya. Uji validitas dianalisis menggunakan program SPSS 22. Jika $r$ hitung $>$ 0,3610 dengan probabilitas 0,05 maka soal dikatakan valid. Reliabel atau tidaknya soal disesuaikan dengan mengklasifikasikan nilai alpha cornbach yang diperoleh seperti pada Tabel 1. Data pretest dan posttest yang diperoleh sebelum dan sesudah pembelajaran selanjutnya dianalisis menggunakan $n$ gain score. Hasil n-gain score terlebih dahulu diuji normalitas dan homogenitasnya untuk menentukan jenis uji statistik yang akan digunakan. Analisis N-gain dapat dilakukan dengan persamaan sebagai berikut:

$$
N-\text { gain }=\frac{S_{\text {post }-} S_{\text {pre }}}{S_{\text {max }}-S_{\text {pre }}}
$$

Kriteria interpretasi N-gain menurut Hake (2002) dapat dilihat pada Tabel 1.

\section{Tabel 1. Kriteria Interpretasi $\mathbf{N}$-gain}

\begin{tabular}{cc}
\hline $\boldsymbol{N}$-gain & Kriteria Interpretasi \\
\hline$N$-gain $>0,7$ & Tinggi \\
$0,3 \leq N$-gain $\leq 0,7$ & Sedang \\
$N$-gain $<0,3$ & Rendah \\
\hline
\end{tabular}


Data yang diperoleh dari rata-rata persentase skor setiap indikator keterampilan proses sains yang diamati pada tiap kelompok. dapat dihitung dengan:

$$
\% \text { KPS }=\frac{\text { Nilai KPS yang diperoleh }}{\text { Nilai Maksimum }} \times 100 \%
$$

Adapun kriteria keterampilan proses sains dapat dilihat pada Tabel 2 yang diadopsi dari Putri, dkk. (2014).

Tabel 2. Kriteria Keterampilan Proses Sains

\begin{tabular}{cl}
\hline Persentase (\%) & Kategori \\
\hline $86-100$ & Sangat Baik \\
$76-85$ & Baik \\
$66-75$ & Cukup \\
$56-65$ & Kurang \\
$\leq 55$ & Sangat Kurang \\
\hline
\end{tabular}

Pengujian hipotesis menggunakan uji statistik indpendent sample t-test yang bertujuan untuk mengetahui ada atau tidaknya perbedaan nilai rata-rata. Ukuran besar pengaruh teknik pembelajaran pictorial riddle berbantukan LKPD berbasis inquiry learning terhadap keterampilan proses sains peserta didik dapat diketahui melalui perhitungan effect size dengan menggunakan rumus Cohen's sebagai berikut:

$$
d=\frac{\bar{X}_{t}-\bar{X}_{c}}{S_{\text {pooted }}}
$$

$S_{\text {pooted }}$ dapat diperoleh dengan menggunakan rumus:

$$
S_{\text {pooted }}=\sqrt{\frac{\left(n_{1}-1\right) S d_{1}^{2}+\left(n_{2}-1\right) S d_{2}^{2}}{n_{1}+n_{2}}}
$$

Hasil perhitungan nilai d kemudian diinterpretasikan berdasaran kriteria Cohen (1988: 82) yang dapat dilihat pada Tabel 4.

Tabel 4. Kriteria Effect Size

\begin{tabular}{ll}
\hline Effect Size & Interpretasi \\
\hline $0,8 \leq \mathrm{d} \leq 2,0$ & Besar \\
$0,5 \leq \mathrm{d}<0,8$ & Rata-rata \\
$0,2 \leq \mathrm{d}<0,2$ & Kecil \\
\hline
\end{tabular}

\section{HASIL}

Penelitian ini dilaksanakan di kelas VIII-a dan VIII-b sebagai kelas eskperimen dan kelas kontrol yang berisi 28 siswa. Kelas eksperimen diberikan pembelajaran dengan teknik pictroial riddle berbantukan LKPD berbasis inquiry learning dan kelas kontrol menggunkan pembelajaran konvensional dengan model direct instruction. Pada kelas eksperimen dan kelas kontrol pelaksanaan pemebelajaran pada pertemuan pertama, dan ketiga dilakukan dengan alokasi waktu 2 x 45 menit 
dan pertemuan kedua dengan alokasi waktu 3 x 45 menit. Hasil uji validitas soal yang memenuhi kriteria kelayakan dari 12 soal adalah sebanyak 9 soal yang dinyatakan valid dan reliabel dengan Cronbach's $A$ lpha sebesar 0,722 yang berarti soal tersebut memiliki reliabilitas yang tergolong tinggi.

Data rerata $N$-gain hasil belajar pada aspek keterampilan proses sains melalui pretest dan posttest dari kedua kelas dapat dilihat pada Tabel 5.

Tabel 5. Data Rerata N-gain Keteampilan Proses Sains

\begin{tabular}{llll}
\hline \multirow{2}{*}{ Kelas } & \multicolumn{3}{c}{$\boldsymbol{N}$-gain } \\
\cline { 2 - 4 } & Terendah & Tertinggi & Rerata \\
\hline Eksperimen & 0,50 & 0,82 & 0,65 \\
Kontrol & 0,11 & 0,44 & 0,27 \\
\hline
\end{tabular}

Berdasarkan Tabel 5 diketahui bahwa rata-rata peningkatan hasil belajar aspek pada keterampilan proses sains kelas eksperimen berada pada kriteria $\mathrm{N}$-gain tinggi dan rata-rata peningkatan hasil belajar pada aspek keterampilan proses sains kelas kontrol berada pada kriteria $N$-gain rendah.

N-gain yang telah diperoleh selanjutnya diuji normalitasnya. Hasil uji normalitas $N$-gain dapat dilihat pada Tabel 6 .

Tabel 6. Hasil Uji Normalitas $\mathbf{N}$-gain

\begin{tabular}{clll}
\hline & \multicolumn{3}{c}{ Asymp Sig. (2-tailed) } \\
\hline Jenis Data & Eksperimen & Kontrol & Kesimpulan \\
$N$-gain & 0,20 & 0,20 & Normal \\
\hline
\end{tabular}

Berdasarkan Tabel 6 diketahui bahwa N-gain pada kelas eksperimen dan kelas kontrol berdistribusi normal. Hal ini dikarenakan hasil uji normalitas N-gain kedua kelas menunjukan nilai Asymp. Sig (2-tailed) sebesar 0,20 pada kelas eksperimen dan 0,20 pada kelas kontrol dengan tingkat signifikansi di atas 0,05 . Hasil yang diperoleh dari uji normalitas ini merupakan syarat terpenuhinya untuk melakukan uji dua sampel yang tidak berpasangan dengan menggunakan Independent Sample T-test.

Hasil uji homogenitas $N$-gain kognitif pada aspek keterampilan proses sains dapat dilihat pada Tabel 7.

\section{Tabel 7. Hasil Uji Homogenitas $\mathbf{N}$-gain}

\begin{tabular}{cccc}
\hline Levene Statistic & df1 & df2 & Sig. \\
\hline 0,866 & 1 & 54 & 0,356 \\
\hline
\end{tabular}

Berdasarkan Tabel 7 dapat diketahui bahwa nilai sig. 0,356 dengan signifikansi $\geq 0,05$, maka dapat disimpulkan bahwa kedua kelompok data memiliki varian yang sama atau homogen.

Data persentase rata-rata keterampilan proses sains yang diperoleh dengan menggunaan lembar observasi di kelas eksperimen dapat dilihat pada Tabel 8. 


\section{Tabel 8. Data Keterampilan Proses Sains Peserta Didik Kelas Eksperimen}

\begin{tabular}{lcc}
\hline \multicolumn{1}{c}{ Aspek KPS } & $\begin{array}{l}\text { Persentase } \\
\text { Keterlaksanaan }\end{array}$ & Kriteria KPS \\
\hline Mengamati & $81,25 \%$ & Baik \\
Berhipotesis & $77,08 \%$ & Baik \\
Menginterpretasi Data & $81,25 \%$ & Baik \\
\hline
\end{tabular}

\section{PEMBAHASAN}

Tujuan dilakukannya penelitian ini adalah mengetahui pengaruh teknik pembelajaran pictorial riddle berbantukan LKPD berbasis inquiri learning terhadap keterampilan proses sains peserta didik. Penelitian ini penting dilakukan karena mengingat akan adanya tuntutan pendidikan abad-21 dimana guru harus memiliki kemampuan menerapkan pembelajaran yang bersifat student centered. Salah satu teknik pembelajaran yang mendukung pembelajaran abad-21 adalah teknik pembelajaran pictorial riddle. Teknik pembelajaran pictorial riddle mampu melatihkan keterampilan proses sains, salah satunya adalah keterampilan berpikir kritis dan keterampilan pemecahan masalah fisika, sehingga dapat memenuhi salah satu tuntutan pendidikan abad-21.

Hasil uji hipotesis menggunakan independent sample t-test menunjukkan nilai Sig. (2-tailed) sebesar 0,000 dengan nilai signifikansi $<0,05$, maka dapat dinyatakan bahwa $\mathrm{H}_{0}$ ditolak. Hasil uji Independent Sample T-test membuktikan bahwa terdapat perbedaan keterampilan proses sains peserta didik antara kelas eksperimen dan kelas kontrol secara signifikan. Berdasarkan hasil uji tersebut, maka dapat disimpulkan bahwa terdapat pengaruh teknik pembelajaran pictorial riddle berbantukan LKPD berbasis inquiry learning terhadap keterampilan proses sains peserta didik pada ranah kognitif pemantulan cahaya. Pernyataan ini relevan dengan penelitian (Yunita et al., 2017) yang pada penelitiannya diperoleh $t_{\text {hitung }}>\mathrm{t}_{\text {tabel }}$, yang berarti bahwa keterampilan proses sains peserta didik yang menggunakan pembelajaran model inquiry dengan teknik pictorial riddle jauh lebih baik dari pemebelajaran yang hanya menggunakan model inquiry saja tanpa teknik pictorial riddle. Pendapat tersebut didukung oleh (Ambarsari et al., 2013), bahwa pembelajaran inkuiri terbimbing memberikan pengaruh yang signifikan terhadap pemahaman konsep dan keterampilan proses sains. Kebaharuan dari penelitian ini adalah pada penelitian sebelumnya pembelajaran dengan teknik pictorial riddle dengan model inquiry learning dilakukan tanpa menggunakan media pembelajaran, sedangkan pada penelitian yang dilakukan oleh peneliti pembelajaran teknik pictorial riddle dilengkapi dengan media berupa LKPD berbasis inquiry learning, sehingga peserta didik lebih mudah dalam melakukan penyelidikan dan pemecahan masalah pada proses pembelajaran. 
Hasil dari perhitungan effect size diperoleh angka sebesar 0,91, angka ini menunjukkan bahwa penggunaan teknik pembelajaran pictorial riddle berbantukan LKPD berbasis inquiry learning yang digunakan pada penelitian ini memiliki pengaruh yang besar. Besarnya pengaruh yang ditimbulkan diakibatkan oleh adanya perbedaan peningkatan nilai rerata kognitif pada aspek keterampilan proses sains dikelas eskperimen dan kelas kontrol dapat dilihat dari perbedaan teknik dan model yang diterapkan oleh peneliti dalam proses pembelajaran. Hal ini relevan dengan penelitian yang telah dilakukan oleh (Chusni, 2016) bahwa teknik pictorial riddle dapat mengembangkan aktivitas siswa pada saat proses pembelajaran berlangsung melalui masalah yang disajikan dalam bentuk ilustrasi sehingga mampu melatihkan kemampuan peserta didik dalam proses pemecahan masalah, dan menurut (Wahyuni et al., 2017) berpendapat bahwa model pembelajaran inkuiri dengan metode eksperimen dapat menjadikan peserta didik lebih aktif. Selain itu menurut (Jannah et al., 2017) bahan ajar yang telah dikembangkan dan diajarkan dengan model inquiry learning efektif melatihkan keterampilan proses sains peserta didik.

Sesuai dengan pendapat (Tauhidah \& Suciati, 2015) keterampilan mengamati dengan baik berarti bahwa peserta didik mampu menggunakan alat inderanya untuk mengenali, memeperhatikan, mencari persamaan dan perbedaan suatu benda atau peristiwa pemantulan cahaya pada cermin datar, cembung, dan cekung dengan tepat. Keterampilan berhipotesis dengan baik berarti bahwa peserta didik mampu mengemukakan dugaan sementara yang dapat menggambarkan sifat-sifat suatu benda atau peristiwa melalui informasi yang telah diperoleh dari kegiatan pengamatan dengan logis. Keterampilan menginterpretasi data dengan baik berarti bahwa peserta didik mampu mencatat hasil-hasil pengamatan kemudian menghubungan hasil pengamatan dengan konsep dan teori sehingga diperoleh suatu kesimpulan dengan tepat.

\section{PENUTUP}

Berdasarkan data hasil penelitian dan pembahasan, dapat disimpulkan bahwa terdapat pengaruh yang signifikan pada pembelajaran yang menggunakan teknik pictorial riddle berbantukan LKPD berbasis inquiry learning terhadap keterampilan proses sains. Pengaruh tersebut ditunjukan dari adanya perbedaan $N$-gain yang signifikan. Sehingga dapat disimpulkan bahwa teknik pictorial riddle berbantukan LKPD berbasis inquiry learning berpengaruh dalam meningkatkan keterampilan proses sains peserta didik. Pembelejaran teknik pictorial riddle berbantukan LKPD berbasis inquiry learning merupakan pembelajaran yang mengandalkan visualisasi permasalahan yang disajikan dalam bentuk gambar, sehingga akan lebih baik jika dilaksanakan dengan menggunakan gambar 3D atau gambar bergerak agar peserta didik lebih mudah mengamati orientasi masalah. 


\section{REFERENSI}

Al, H., Subali, B., \& Rusilowati, A. (2018). Penerapan model pembelajaran Inquiry Pic t orial Riddle untuk meningkatkan keaktifan siswa The Implementation of Inquiry Pictorial Riddle Learning Model to Increase Students' Activity. Jurnal Pendidikan Fisika Dan Keilmuan (JPFK). https://doi.org/10.2572/jpfk.v4i2.1879

Ambarsari, W., Santosa, S., \& Maridi, M. (2013). Penerapan Pembelajaran Inkuiri Terbimbing Terhadap Keterampilan Proses Sains Dasar pada Pelajaran Biologi Siswa Kelas VIII SMP Negeri 7 Surakarta. Jurnal Pendidikan Biologi Universitas Sebelas Maret.

Anggraini, A. E., Hamid, A., Yusandika, A. D., \& Susilowati, N. E. (2018). Pengaruh Metode Pictorial Riddle Yang Dimodifikasi Dengan Pendekatan Scientific. Journal of Science and Mathematics Education.

BSNP. (2010). Paradigma Pendidikan Nasional Abad XXI. Paradigma Pendidikan Nasional Abad XXI.

Chusni, M. M. (2016). Penerapan Pendekatan Inkuiri Terbimbing dengan Metode Pictorial Riddle untuk Meningkatkan Pemahaman Konsep Fisika Siswa. Jurnal Pendidikan Fisika. https://doi.org/10.24127/jpf.v4i2.540

Jannah, L., Nur, M., \& Suyono, S. (2017). Desain Bahan Ajar Materi Gelombang Dan Bunyi Model Inkuiri Terbimbing Untuk Melatihkan Keterampilan Proses Sains Siswa Smp. JPPS Jurnal Penelitian Pendidikan Sains), 6(1), 1196. https://doi.org/10.26740/jpps.v6n1.p1196-1203

Paul M. Muchinsky. (2012). Psychology Applied to Work: An Introduction to Industrial and Organizational Psychology, Tenth Edition Paul, 53(9), 1689-1699. https://doi.org/10.1017/CBO9781107415324.004

Sujadi, E. (2019). Penerapan Play Therapy dengan Menggunakan Permainan Tradisional untuk Meningkatkan Keterampilan Sosio Emosional. Jurnal Bimbingan Dan Konseling Terapan, 3(1), 14-24. https://doi.org/https://doi.org/10.30598/jbkt.v3i1.892

Sujadi, Eko. (2018). Kode Etik Profesi Konseling Serta Permasalahan dalam Penerapannya. Tarbawi: Jurnal Ilmu Pendidikan, 14(2), 69-77. https://doi.org/10.32939/tarbawi.v14i2.298

Sujadi, Eko, \& Meditamar, M. O. (2020). Perbedaan Locus of Control ditinjau dari Perspektif Agama pada Siswa SMA. Analitika: Jurnal Magister Psikologi UMA, 12(1), 44-54. https://doi.org/http://dx.doi.org/analitika.v11i1.3506

Tauhidah, D., \& Suciati, D. (2015). Perbandingan Peningkatan Keterampilan Proses Sains Dan Kemampuan Kognitif Siswa Pada Penerapan Model Guided Inquiry Laboratory. Prosiding Seminar Nasional Pendidikan Sains.

Wahyuni, R., Hikmawati, H., \& Taufik, M. (2017). Pengaruh Model Pembelajaran Inkuiri Terbimbing dengan Metode Eksperimen terhadap Hasil Belajar Fisika Siswa Kelas XI IPA SMAN 2 Mataram Tahun Pelajaran 2016/2017. Jurnal Pendidikan Fisika Dan Teknologi. https://doi.org/10.29303/jpft.v2i4.308

Yunita, Y., Syuaib, M. Z., \& Taufik, M. (2017). Perbedaan Hasil Keterampilan Proses Sains Melalui Model Pembelajaran Inquiry dan Model Pembelajaran Inquiry dengan Metode Pictorial Riddle bagi Siswa SMP Negeri 1 Gunungsari Tahun Ajaran 2015/2016. Jurnal Pendidikan Fisika Dan Teknologi. https://doi.org/10.29303/jpft.v2i1.286 